\title{
Antecedent Factors of Financial Management Behavior: An Empirical Research Based on Education
}

Lulu Amalia Nusron, Mutiara Wahidiyah, and Dekeng Setyo Budiarto

Department of Accounting, Universitas PGRI Yogyakarta

\section{Abstract}

Bad financial attitudes, such as wasting of money, are really difficulties to remove from Indonesian culture. The issue of financial management behavior has attractive agendas for educators, business and government agencies. The purpose of this study is to examine the effect of financial attitude, financial knowledge and personal income on financial management behavior. The research data were obtained from 94 students of Bachelor, Masters and Doctoral programs at various universities in Special

Corresponding Author: Dekeng Setyo Budiarto dekengsb@upy.ac.id

Received: 7 August 2018 Accepted: 15 September 2018 Published: 22 October 2018

Publishing services provided by Knowledge E

(c) Lulu Amalia Nusron et al. This article is distributed under the terms of the

Attribution License, which permits unrestricted use and redistribution provided that the original author and source are credited.

Selection and Peer-review under the responsibility of the ICE-BEES 2018 Conference Committee

\section{G OPEN ACCESS} Region of Yogyakarta and Central of Java with convenience sampling method. The quality of data generated by this research instrument was assessed using validity and reliability tests. Hypotheses were tested using multiple regression analysis to determine the effect of independent variables on financial management behavior. The results showed that financial attitude, financial knowledge and personal income have a significant effect on financial management behavior.

Keywords: financial attitude, financial knowledge, personal income, financial management behavior.

\section{Background}

Based on conventional financial theory, the world and financial practitioners want to be "Wealth Maximize" and, correspondingly, one important concept in financial science is financial management behavior [2]. An educated and experienced person often has difficulty in dealing with debt burdens and paying off the loan in a timely manner. Responsible use of money will usually gain more attention from individuals with established income [12]. A person living on low income is less likely to be on time to pay bills. This relates to a financial management behavior that indicates a person's responsible use of money representing his or her habits of financial management [9].

Expanded access to financial services brings people the opportunity to have a safe place, to insure themselves against the risks of poverty and poor health, and to get 
loans to build their business [12]. Some evidence suggests that financial attitude is related to the financial difficulties most societies are facing $[8,14]$. Therefore, individuals need financial knowledge to bring them economic benefits [11]. Several earlier studies have attempted to establish a correlation between financial behavior and financial education [22]; welfare [21]; social marketing [12]. They are interesting because of their found mix evidence [5]. Previous studies have shown that financial attitude and financial knowledge have an effect on financial management behavior $[2,8,11]$. Conversely, some other researchers argue that financial attitude and financial knowledge have no effect on financial management behavior $[13,15]$. This study aims to examine the influence of financial attitude, financial knowledge and personal income on financial management behavior. Moreover, this study examines differences in financial management behavior based on education, which has never been studied before.

\section{Previous Researches and Hypotheses}

Financial behavior or financial attitude of a person came out of the individual's attitude toward unwise financial decision. Individuals tend to engage in unwise behavior when it comes to dealing with financial difficulties [16]. Financial behavior that an individual engaged in has something to do with financial management behavior as the former can be measured by the individual's action. Financial attitude determines how a person would spend, save, accumulate or even waste his or her money [7]. Based on the above descriptions, it can be said that financial attitude affects a person's habit of financial management or his financial management behavior. Therefore, the first hypothesis can be stated as follows:

\section{H1: Financial attitude has an significant effect on financial management behavior.}

To attain financial stability, every individual should have the ability to manage his personal daily cash flow. Such ability comprises knowledge of personal finance or, more precisely, financial knowledge [6]. To gain financial knowledge, it is necessary to develop financial skill and to learn how to use financial tools. By financial skills we mean techniques for making decisions in personal financial management. As for financial tools, they are forms and charts used in personal financial management decisionmaking [3]. Habits in the management of personal decisions are referred to as financial management behaviors. As the above descriptions suggest, financial knowledge has 
an effect on financial management behavior, thus the second hypothesis can be stated as follows:

H2: Financial knowledge has an significant effect on financial management behavior.

Income plays a significant role in daily financial plans of each individual. It is highly likely that individuals with high income will show better financial management behavior considering that the available funds at their disposal give them opportunity to act responsibly. Previous researches have made it clear that low income people are less timely in paying bills and are less likely to engage in financial activities such as saving $[9,18]$. As described previous, income has an effect on financial management behavior; therefore, the third hypothesis can be stated as follows:

H3: Personal income has an significant effect on financial management behavior.

Varying educational backgrounds do affect the individual behavior in devising his financial plans. Previous researcher found that many graduates are not able to manage their finances due to debt burden during their study period [6]. Previous researcher argues that financial knowledge is not related to education [23]. Other researchers, on the contrary, find that the higher the educational level, the higher the level of knowledge about financial management $[1,17]$. Based on the findings of previous researches, the fourth hypothesis can be stated as follows:

H4: There is difference perception on the financial management behavior based on educational level.

\section{Research method}

The present study employs a qualitative research method by distributing questionnaires to the respondents. We use purposive sampling technique to conduct the entire sampling process. The study took a sample of 94 students comprising of 24 from bachelor program, 59 from master program, and 11 from doctoral program. The respondents were students in a number of universities in the special region of Yogyakarta and Central Java. All statement items will be measured using 5 point Likert scale from point 1 (strongly agree) to point 5 (strongly disagree). 


\section{Measurement of variables}

\subsection{Financial attitude}

Financial attitude is related to the financial difficulties people are facing [14]. There are six concepts that reflect attitude toward money: obsession, power, retention, security/conservative, inadequacy and effort/ability. One of these refers to the concept of financial attitude, i.e. effort/ability [7].

\subsection{Financial knowledge}

An individual with financial knowledge will be more financially responsible. Financial knowledge is an aspect of financial management behavior that is indicated by the understanding of credit and interest, investment and financial management $[6,9]$.

\subsection{Personal income}

Personal income is the total gross earnings of an individual for financial activities. The indicator variable is adopted from [11] modified by adjusting the earlier measurement using numeric data into a scale to generate unbiased results.

\subsection{Financial management behavior}

A person knowledgeable about factors in making decisions and lifestyles is an efficient person in financial management behavior. The research indicator presented financial plans related to monthly bills and savings [3].

\section{Result}

The result of validity test using Pearson correlation (Table 1 ) shows that all indicators are valid, while the reliability test (Table 2), using Cronbach alpha, shows that all research variables are reliable. Examples of validity test result are show in table 1. 
TABLE 1: The results of validity testing for financial attitude.

\begin{tabular}{|c|c|c|}
\hline No & Statement & $\begin{array}{l}\text { Pearson } \\
\text { correlation }\end{array}$ \\
\hline 1 & $\begin{array}{l}\text { I believe that the amount of money someone earns } \\
\text { are very much related to his ability and effort to get it. }\end{array}$ & $0.633^{* \star}$ \\
\hline 2 & I believe that my current income belongs to me. & $0.499^{\star \star}$ \\
\hline \multirow[t]{2}{*}{3} & $\begin{array}{l}\text { I believe that my current income is a lot lower than } \\
\text { the expected for the job }\end{array}$ & $0.464 * *$ \\
\hline & I have done. & \\
\hline 4 & $\begin{array}{l}\text { I believe that I have been less willing to change my } \\
\text { financial situation even though I have the ability to so. }\end{array}$ & $0.758^{* \star}$ \\
\hline \multicolumn{3}{|c|}{$\star \star \operatorname{Sig}<1 \%$} \\
\hline
\end{tabular}

TABLE 2: The results of reliability testing.

\begin{tabular}{l|c|c|c|}
\hline Variable & Indicator & Cronbach Alpha & Description \\
\hline Financial Attitude & 4 & 0.720 & Reliable \\
\hline Financial Knowledge & 5 & 0.784 & Reliable \\
\hline $\begin{array}{l}\text { Personal Income } \\
\text { Financial Management } \\
\text { Behavior }\end{array}$ & 2 & 0.743 & Reliable \\
\hline
\end{tabular}

TABLE 3: The results of hypothesis testing (Multiple Regression).

Variable
Financial Attitude
Financial Knowledge
Income

\begin{tabular}{|c|c|c|}
\hline B & t value & Sig \\
\hline 0.325 & 3.076 & $0.001^{\star}$ \\
\hline 0.272 & 2.868 & $0.005^{\star}$ \\
\hline 0.300 & 2.231 & $0.028^{\star}$ \\
\hline
\end{tabular}

Decision
$\mathrm{H}_{1}$ :Supported
$\mathrm{H}_{2}$ :Supported
$\mathrm{H}_{3}$ :Supported

$F$ Value: 12.126; Adj R Square $=0.288$

* $\operatorname{Sig}<5 \%$

TABLE 4: The results of hypothesis testing for financial management behavior (ANOVA).

\begin{tabular}{|c|c|c|c|c|c|}
\hline \multirow[b]{2}{*}{ Indicator } & \multicolumn{3}{|c|}{ Mean } & \multirow[b]{2}{*}{$F_{\text {value }}$} & \multirow[b]{2}{*}{ Sig } \\
\hline & Bachelor & Master & Doctoral & & \\
\hline I can control my spending. & 3.17 & 3.83 & 4.36 & 16.804 & $0.000^{* *}$ \\
\hline $\begin{array}{l}\text { I pay my bills in a timely } \\
\text { manner. }\end{array}$ & 3.25 & 3.95 & 4.82 & 21.631 & $0.000 * *$ \\
\hline $\begin{array}{l}\text { I am planning for my financial } \\
\text { future. }\end{array}$ & 3.08 & 4.12 & 4.82 & 53.831 & $0.000 * *$ \\
\hline $\begin{array}{l}\text { I set aside some money for } \\
\text { myself and }\end{array}$ & 3 & 4.1 & 4.64 & 30.139 & $0.000 * *$ \\
\hline \multicolumn{6}{|l|}{ my family. } \\
\hline I keep some money for savings. & 3.08 & 4.05 & 4.5 & 36.498 & $0.000 * *$ \\
\hline
\end{tabular}




\section{Discussion}

The results of the study showed that financial attitude have an significant effect on financial management behavior ( $H_{1}$ supported). Financial attitude is a person's state of mind, opinion and judgment on his financial situation, which is then manifested in his attitude. The opinion and judgment on his financial situation will determine his conduct in performing financial activities $[2,8,10]$.

The results indicated that financial knowledge has an significant effect on financial management behavior ( $\mathrm{H}_{2}$ supported). These results confirmed an previous research, which state that financial knowledge, referred to as financial education, will affect several benefits in improving the financial management behavior, such as skills, selfconfidence, and decision-making in financial behavior [22].

The results proved that personal income affects management financial behavior $\left(\mathrm{H}_{3}\right.$ supported). Financial independence could affect a person's behavior in financial management. A person who earns his own income would feel more freedom in managing his expenses [19].

The results showed that differences exist in financial management behavior based on educational level ( $\mathrm{H}_{4}$ supported). Educational level serves as an indicator for a person's intellect. The higher a person's educational level, the higher the level of his knowledge and intellect will be. With an adequate level of education, it will be easier for a person to carry out his duties in managing his money properly [4]. Therefore, high level of education strengthens individuals' capacity in making their financial decision properly and positively affects their financial knowledge [20].

\section{Conclusion, Limitations and Suggestions}

Based on the data analysis, it can be concluded that all hypotheses are supported: that financial attitude, financial knowledge and income have a significant effect on financial management behavior. Moreover, differences exist in financial management behavior based on educational level. This study has some limitations that need to be pointed out. First, several questions in the questionnaire share

similarities that lead respondents to give ambiguous answers. For that reason, we suggest that future studies avoid questions that almost similar to each other that enables respondents to give straight answers [6]. Second, this study uses two research variables which are elements of psychology: attitude and knowledge. Therefore, it is expected that future studies use other factors than psychological elements in order to 
generate dominant effect in the application of financial management behavior [10]. Third, the current study examines direct relationship between financial knowledge as the independent variable and financial management behavior as the dependent variable. We suggest for future studies to examine those variables as the mediating variables [22].

\section{References}

[1] Albeerdy, M. I., \& Gharleghi, B. (2015). Determinants of the financial literacy among college students in Malaysia. International Journal of Business Administration, 6(3), 15.

[2] Amanah, E., Rahadian, D., \& Iradianty, A. (2016). Pengaruh Financial Knowledge, Financial Attitude Dan External Locus Of Control Terhadap Personal Financial Management Behavior Pada Mahasiswa S1 Universitas Telkom. eProceedings of Management, 3(2).

[3] Arifin, A. Z. (2017). The Influence of Financial Knowledge, Control and Income on Individual Financial Behavior. European Research Studies, 20(3A), 635.

[4] Darwanis, N., \& Abdullah, S. (2014). Pengaruh tingkat pendidikan, pelatihan dan pemahaman akuntansi terhadap ketepatan waktu penyampaian laporan keuangan SKPK pada Pemda Aceh Timur. Jurnal Administrasi Akuntansi: Program Pascasarjana Unsyiah, 3(3), 59-68.

[5] Fernandes, D., Lynch Jr, J. G., \& Netemeyer, R. G. (2014). Financial literacy, financial education, and downstream financial behaviors. Monagement Science, 60(8), 18611883.

[6] Fiksenbaum, L., Marjanovic, Z., \& Greenglass, E. (2017). Financial threat and individuals' willingness to change financial behavior. Review of Behovioral Finance, 9(2), 128-147.

[7] Furnham, A. (1984). Many sides of the coin: The psychology of money usage. Personality and individual Differences, 5(5), 501-509.

[8] Herdjiono, I., \& Damanik, L. A. (2016). Pengaruh Financial Attitude, Financial Knowledge, Parental Income Terhadap Financial Management Behavior. Jurnal Manajemen Teori dan Terapan/Journal of Theory and Applied Management, 9(3), 226241.

[9] Hilgert, M. A., Hogarth, J. M., \& Beverly, S. G. (2003). Household financial management: The connection between knowledge and behavior. Fed. Res. Bull., $89,309$. 
[10] Humaira, I., \& Sagoro, E. M. (2018). Pengaruh pengetahuan keuangan, sikap keuangan, dan kepribadian terhadap perilaku manajemen keuangan pada pelaku UMKM sentra kerajinan batik KABUPATEN BANTUL. Nominal, Barometer Riset Akuntansi dan Manajemen, 7(1).

[11] Ida, I. D. A., \& Dwinta, C. Y. (2010). Pengaruh Locus Of Control, financial knowledge, income terhadap financial management behavior. Jurnal Bisnis dan Akuntansi, 12(3), $131-144$.

[12] Lee, N. R., \& Miller, M. (2012). Influencing positive financial behaviors: the social marketing solution. Journal of Social Marketing, 2(1), 70-86.

[13] Lianto, R., \& Megawati Elizabeth, S. (2018). Analisis pengaruh financial attitude, financial knowledge, income terhadap financial behavior (Studi KasusKecamatan Ilir Timur I). e-journal, STIE MDP, 1, 1-10.

[14] Lim, V. K. G., \& Teo, T. S. H. (1997). Sex, money and financial hardship: An empirical study of attitudes towards money among undergraduates in Singapore. journal of Economic Psychology, 18(4), 369-386.

[15] Listiani, K. (2017). Pengaruh financial knowledge, locus of control dan financial attitude terhadap financial management behavior pada mahasiswa. STIE PERBANAS SURABAYA.

[16] Marsh, B. A. (2006). Examining the personal finance attitudes, behaviors, and knowledge levels of first-year and senior students at Baptist universities in the state of Texas. Bowling Green State University.

[17] Peng, T.-C. M., Bartholomae, S., Fox, J. J., \& Cravener, G. (2007). The impact of personal finance education delivered in high school and college courses. Journal of family and economic issues, 28(2), 265-284.

[18] Perry, V. G., \& Morris, M. D. (2005). Who is in control? The role of selfâ€ perception, knowledge, and income in explaining consumer financial behavior. Journal of Consumer Affairs, 39(2), 299-313.

[19] Shim, S., Barber, B. L., Card, N. A., Xiao, J. J., \& Serido, J. (2010). Financial socialization of first-year college students: The roles of parents, work, and education. Journal of youth and adolescence, 39(12), 1457-1470.

[20] Vyvyan, V., Blue, L., \& Brimble, M. (2014). Factors that influence financial capability and effectiveness: Exploring financial counsellors' perspectives. Australasian Accounting Business \& Finance Journal, 8(4), 3.

[21] Xiao, J. J., \& O'Neill, B. (2016). Consumer financial education and financial capability. International Journal of Consumer Studies, 40(6), 712-721. 
[22] Xiao, J. J., \& Porto, N. (2017). Financial education and financial satisfaction: Financial literacy, behavior, and capability as mediators. International Journal of Bank Marketing, 35(5), 805-817.

[23] Zaimah, R., Sarmila, M. S., Lyndon, N., Azima, A. M., Selvadurai, S., Saad, S., et al. (2013). Financial behaviors of female teachers in Malaysia. Asian Social Science, 9(8), 34. 